\title{
Narrative Identity Constructs and Effects on Performance in the Field of Sports
}

\author{
PAOLA BRIGANTI \\ paola.briganti@uniparthenope.it \\ University of Naples Parthenope \\ LUISA VARRIALE \\ varriale@uniparthenope.it \\ University of Naples Parthenope
}

\author{
STEFANIA MELE \\ melest@gmail.com \\ University of Naples Parthenope
}

\begin{abstract}
The exposure to numerous and challenging changes and pressures in the contemporary world (i.e., the development of new technologies, current socio-demographic processes, financial and economic crises, organisational reshaping, societal values changes, etc.) significantly affects how individuals live. In such a context, people therefore need to completely rethink and reshape their way of behaving to face several difficulties, especially for expressing themselves, preserving their own identity, and respecting their societal and cultural values. It is not easy to keep and express our own identity in a contemporary society characterised by high pluralism and multiculturalism, where the new generations need in particular to feel accepted by the world and do not often adhere to their authentic way of being and behaving. For this reason, narrative identity constructs have been receiving increasing attention by scholars and practitioners trying to search for and identify the most effective ways for individuals in any setting to describe themselves, achieving the best performance and high levels of well-being in everyday life. In sports, the debate on this issue is still open, with much more emphasis on the effects of narrative identity constructs on the athletes' performance. Therefore, by adopting a qualitative methodology and using a manual content analysis technique, the present explorative study investigates narrative identity as a possible effective path for individuals to face their everyday life challenges, trying to keep their strong values and their own ways of being and behaving. The purpose is to analyse identity markers and pointers through the narrative identity constructs with direct and indirect connections to the setting of sports, particularly with a specific focus on athletes' performance. The investigation of the relationship between specific topics (i.e., presence/absence of purpose and meaning, positive/negative self-representation, positive/negative relationships) for athletes involved in sports competitions, outlining their ways of describing and talking about themselves. The
\end{abstract}


results of this study outline that individual characteristics significantly affect the athletes' storytelling style and sports performance. These findings can support coaches and personal trainers, as well as athletes, to identify and implement effective practices for improving their narrative identity, such as adequate training and effective educational programmes for their self-awareness.

\section{Introduction}

In the last decades, contemporary society has completely changed and has been changing in priorities, values, and organisational and behavioural models. As a result, we observe and need to face new challenges that have implications that are extremely hard to manage and face. For instance, the development, adoption and spread of new technologies have completely reshaped the meaning of work division and coordination, as well as the way of communicating, whereas the borders between individuals within and outside organisations have become highly flexible and almost absent (Adisa et al., 2017; Guzman and Lewis, 2020; Wang et al., 2020). Furthermore, financial and economic crises and deep global sociodemographic processes have contributed remarkably to defining new and challenging ways of co-existing with different societal and cultural values, where it is exceedingly difficult to retain our own mental and behavioural models (Leiser et al., 2016; Gallie, 2019; Trinh et al., 2020).

In the scenario briefly described, each individual may feel lost because they might not truly express themselves. Indeed, it can be incredibly challenging for each individual to keep their identity in contemporary society where pluralism is dominant, and several global pressures may overwhelm the individual identities. It is almost like the overall society is pushing individuals to homologate themselves, thus losing the characteristics and specificities of their identity so as to adhere to the new societal system, where it is relevant how each individual appears to others and how they describe themselves and respect the most common, acknowledged and successful models (Basu and Kumar, 2020; Ferreri, 2020).

On the basis of this background, this conceptual study aims to investigate narrative identity constructs, consisting of the use of storytelling by individuals about their past for being able to face the challenging future, having the right consideration of themselves. More specifically, by adopting a qualitative methodology and using content analysis, this explorative study provides a reading of the phenomenon 'narrative identity' within one specific field, that is, the setting of sports. The context of sports has been chosen for two main reasons: firstly, because of the significant increase and relevance of sports business in the last decades, where we observe an impressive growth in terms of volumes of revenues for sports organisations and athletes in many sports disciplines, as well as, increasing attention paid to this field by scholars and practitioners, also to search for more effective solutions able to improve the performance (Den Hartigh et al., 2018; Rizvandi et al., 2019; Pitts and Zhang, 2020). Additionally, sport plays a crucial role as a means for promoting and stimulating social inclusion for everyone, especially for people with disability, whereby individuals can genuinely express themselves and feel to be truly part of a group (Haudenhuyse, 2017; Peachey et al., 2019; Cunningham et al., 2020).

More precisely, this study investigates identity matters through narrative identity constructs with direct and indirect connections to the setting of sports, with particular attention to 
athletes' performances. Indeed, the relationship between specific topics (i.e., presence/absence of purpose and meaning, positive/negative self-representation, positive/negative relationships, etc.) for athletes involved in sports competitions is investigated, outlining their ways of describing and talking about themselves. It is crucial to underline that further demands could predispose athletes to much more significant risks of suffering from mental health issues, such as depression, when they are unable to tackle any of the challenges they face, with symptoms that include hopelessness, irritability, emptiness, despair, chronic fatigue, denial, lack of acceptance by peers, isolation, low self-esteem, anxiety, pain, and regret among others (Etzel, 2006; Sarokhani et al., 2013). Scholars have indicated that depression is a primary mental health concern among athletes who lose purpose and meaning and develop negative self-perception and relationships (Storch et al., 2002; Rao and Hong, 2016). In particular, the literature has underlined how female athletes appear to exhibit more severe depressive symptoms than male athletes (Storch et al., 2002; Yang et al., 2007).

Hence, this study provides a summary of narrative identity constructs through the storytelling of sports athletes, outlining how important it is for them the way they represent themselves and their difficulties in facing any difficulties related to their everyday life and sports setting, taking into account their behavioural habits and practices in facing life (i.e., defining goals or meaning, positively or negatively considering themselves, establishing useful or useless relationships, etc.). Although this study is exploratory in its nature, it nonetheless contributes to the existing literature on the topic, thus providing a different interpretation of the phenomenon in the context of sports. Furthermore, such a study will point out if and how some features might play a crucial role and significantly impact athletes' narrative identity and performances.

\section{Narrative identity: a literature review}

Narrative identity is a person's internalised and evolving life story, integrating the reconstructed past and imagined future to provide life with some degree of unity and purpose (McAdams and McLean, 2013: 233). Recent research has focused on two main characteristics of narrative identity: psychological adaptation mechanisms, which allow the stories to act as an instrument of balance or personal psycho-physical imbalance (Bauer et al., 2005; Fivush et al., 2006; McLean and Pratt, 2006; King and Hicks, 2007; McLean et al., 2007), and development of personal story during the different phases of the life through dialogues with parents, friends, colleagues, and, in general, caregivers (Habermas and De Silveira, 2008; Pasupathi and Hoyt, 2010; Syed and Azmitia, 2010; McLean and Pasupathi, 2011; Adler, 2012; McAdams and McLean, 2013).

Psychological adaptation consists of how individuals make narrative sense of suffering in their lives, enacting personal agency, the degree to which individuals describe themselves as able to effect change in their lives or the environment by re-storytelling a successful key narrative theme of their existences. In order to become an adult strengthened and enriched by negative life experiences, an individual generally follows a two-step process (Pals, 2006). In the first phase, people deeply, longingly and hardly explore the negative experience, thinking in detail and thoughtfully, accounting for the loss and struggle in their lives (e.g., child illness, divorce, work problems, severe diseases, etc.). People think about how they felt like, articulating, elaborating and processing the turning points and where the event may lead to 
in their lives. In the second phase, individuals try to position adverse events in their overall life story and engage in a positive perception of the problem as an opportunity to change positively and better manage personal life. The first step should be related to an increase in personal growth, awareness, identity and psychological maturity, while the second one should be linked to peacefulness and happiness (Bauer et al., 2005; McLean and Pratt, 2006; King and Hicks, 2007; Syed and Azmitia, 2010).

Psycho-physical well-being and successful private, social and job performances also depend on the development process of narrative identities (McAdams and McLean, 2013). Over the last century, according to the classical theory of psychosocial development (Erikson, 1963), most authors on the matter have stated that individuals develop the ability to engage in the complex process of narrating stories about the self since their late-adolescent and early-adult years, partly as a function of the biological development of the frontal lobes of formal operational thinking, and partly due to societal expectations regarding identity which let individuals ask themselves existential questions, such as: "Who am I? How did I come to be? Where is my life going?" (McAdams, 1985; Habermas and Bluck, 2000). Conversely, recent research has outlined that the ability to construct, internalise and argue with causal coherence (i.e., a convincing account of how early events cause later events) and thematic coherence (i.e., the derivation of organising themes or trends in an entire life) in narrative identity construction emerges, before adolescence, in late childhood according to a sociocultural model, which highlights that a narrative identity builds slowly over time as people tell stories about their experiences to and with others (McLean et al., 2007; Habermas and De Silveira, 2008).

From a quantitative analysis perspective, self-narrative coherence of individuals' self-storied accounts shows a statistically significant relationship to psychological well-being, in line with narrative psychologists, who argue that mental well-being is undoubtedly related to and, maybe, the result of a well-integrated and coherent self-storied account (Baerger and McAdams,1999).

The ability to construct a coherent account of personal experience results from progressive and adaptive psychological adjustment cuts during life in a reflective and predictive manner. Coherent accounts of identity present significant relations with three psychological well-being components: (a) purpose and meaning, (b) positive self-view, and (c) positive relationships. The identity content of each narrative represents the moderating variable between the narrative coherence of personally significant autobiographical memories and psychological well-being (Waters and Fivush, 2015). Waters and Fivush (2015) collected two autobiographical narratives of personally significant events from 103 undergraduate students and coded them for coherence and identity content. Two other narratives about generic/recurring events were also collected and coded for coherence. They confirm the prediction that constructing coherent self-narratives is related to psychological well-being. Moreover, they demonstrate that this relation is moderated by the autobiographical narratives' relevance to identity (i.e., unique events are a critical feature of identity construction), after testing the moderation role for narrative ability more generally, in terms of coherence of generic and recurring events. On the contrary, failure in developing this kind of coherent account of identity since adolescent and emerging adulthood periods emerges as the result of early and progressive loss of a sense, purpose and meaning in life, a feeling of helplessness, and loss of coherence in self-narrative, thus producing the inability or failure to develop positive intimate relationships (e.g., Erikson, 1950, 1968; McAdams, 1993, 1995, 1996). 
According to McAdams and McLean (2013: 235; see also McLean et al., 2007), over time:

[...] selves create stories, which in turn create selves [...]. Through repeated interactions with others, stories about personal experiences are processed, edited, reinterpreted, retold, and subjected to a range of social and discursive influences, as the storyteller gradually develops a broader and more integrative narrative identity.

Conversations with parents, who use an elaborated dialogical style, focused on causes and explanations underscoring emotional evaluations of past events about personal events, statistically represent a critical issue for the development of constructive or disrupted narrative and meaning-making skills in children (Fivush et al., 2006). Moreover, during individuals' life, attentive and responsive listeners enhance tellers to narrate more personally elaborated stories, despite distracted listeners (Pasupathi and Hoyt, 2010): attentive listening helps tellers promote the development of a narrative identity, and not the process of narrating just to entertain themselves. Finally, from a longitudinal perspective of positive evolution of one's own narrative identity, the development process is positively affected by the level of depth of the relationships and the romantic characteristics of partners (McAdams and McLean, 2013: 235; see also McLean and Pasupathi, 2011):

$[\ldots]$ the more romantic partners agreed on the meaning of a shared memory, the more likely the teller was to retain that meaning over time. Therefore, when important people in a person's life agree with his or her interpretation of a personal story, he or she is likely to hold on to that story and to incorporate it into his or her more general understanding of who he or she is and how he or she came to be.

Self-narrative studies significantly emerge as a relevant concept in the sports field literature and, in particular, in analysing athletic identity after acquiring a physical disability (Sparkes and Smith, 2002; Perrier et al., 2014). For the development and expansion of the social model of disability to incorporate a sociology of body and impairment, Hughes and Paterson (1997) highlight that most research on the inside-out perspectives that features storytelling process of people with disabilities, when they talk about their bodies, adopt an interactionist and selfnarrative identity approach. They notice that, even though this perspective has offered descriptions of the discriminations faced by people with disabilities, much research has always been done to identify the conditions that produce these experiences, bypassing the essential ambiguity of human embodiment as personal and impersonal, objective and subjective, social and natural, to effectively incorporate the complexities of being disabled by locating impairment as a culturally informed and meaningful quality of existence (Hughes and Paterson, 1997: 335):

Disability is experienced in, on and through the body, just as impairment is experienced in terms of the personal and cultural narratives that help to constitute its meaning [...]. Most importantly, the (impaired) body is not just experienced: It is also the very basis of experience. [...] Disability is, therefore, experienced from the perspective of impairment. One's body is one's window on the world. 
According to Marks (1999: 611), "disability does not reside in a particular body or environment, but rather is an embodied relationship and narratives". Therefore, any research on impairment should include a consideration of unconscious experiences of disability and the positive or negative role of conscious narrative accounts. The socially oppressive narrative about disablism can be identified as one of the leading causes of developing unconscious defences used by people with disabilities: to face social oppression narrative pressures, they develop progressive invalidating psychological forms of internalised oppression. Marks (1999) states that it is crucial to examine the relationship that injured people have with others, but also their effects on the relationship they have with themselves.

From a socio-cultural and subjective perspective, self-narrative identity literature can contribute to a cultural understanding of disability and sports. How athletes with disabilities are described within the media (i.e., stories, visual images, etc.) and how much time is dedicated to adapting to sports, which could affect athletic self-narrative development identity (Perrier et al., 2014).

Pappous et al. (2011) analyse the media coverage of three consecutive summer Paralympic Games. The Media coverage of athletes competing resulted low because there are limited worldwide resources to draw on, follow, and develop people with disabilities as athletes. According to these scenarios, it is plausible that athletic identity may be lost after acquiring a physical disability when the prevalent cultural models promote a negative notion of adapted sports as not real sports (Smith and Sparkes, 2012). Furthermore, research suggests that disability narratives impact whether individuals with disabilities consider adapted sports a legitimate physical activity post-injury and their positive or negative self-narrative identity constructions (Perrier et al., 2013).

\section{Storytelling methodology and the theory of narrative identity}

During the last two decades, the narrative approach has had a significant impact on the human and social sciences (Chamberlayne, 2000) and has also found its way to be investigated and adopted into the organisational literature. The narrative form gives meaning and coherence to individual experiences: people rely on it for their day-to-day discourses to shape and, indeed, to construct, present and represent their identities. Consequently, much of the work carried out by researchers in the human sciences has to do with seeking, constructing and deconstructing the individual's life story, by transference and counter-transference reflexive interaction tools and/or content analysis (Covington, 1995: 407).

In particular, the Theory of Narrative Identity (Gergen and Gergen, 1987; Kerby, 1991; Gergen, 1996; Polkinghorne, 1996) considers the identity as the construct which provides the person with a sense of continuity of being over time, thus creating a sense of coherence so that divergent experiences form an interconnected whole, which gives meaning to one's experiences and life as a whole. All these aspects of identity (i.e., continuity, coherence and meaning) are developed by putting one's experiences in life into a life story, a narrative. Therefore, identity necessarily has a narrative form. This is also the reason why in organisational studies, researchers let people tell their life stories or collect them by archival, social media and digital data since, through these narratives, scholars are able to learn about and investigate the personality and the identity of the individuals (Roesler, 2006: 576). 
Covington (1995: 406) continues by arguing that "[b]iography has to do with imposing patterns in order to establish meaning". This is undoubtedly an essential aspect of the narrative approach in social sciences: the events we experience in our lives do not have meaning in and by themselves, but they acquire meaning in acts of interpretation by the experiencing mind (Josselson and Lieblich, 1995). Additionally, experiences do not automatically become coherent, but coherence and continuity are constructions of the individual (Linde, 1993). This happens by imposing patterns on the primary materials of experience. Then, the issues investigated by biography research and, in this case, also by psychological and organisational analysis grounded on narratives are the following ones: which narrative patterns are imposed by a particular individual? Which patterns govern their life course? And where are these patterns taken from?

Jung (1995 [1911-1912/1952]) points out that personal myths, which are archetypal patterns found, for instance, in mythology and fairy tales, could govern the life course of individuals, in most cases unconsciously. Many authors point out clearly that individuals narrating their life stories often use typified story patterns that resemble the well-known narratives of their culture (Mishler, 1986; McAdams, 1993). The psychologist Bruner (1995), for instance, maintains that many storytellers use the classical forms of comedy and tragedy or the hero story pattern in shaping their personal stories. Lieblich (1998) argues that, from the 1960s onwards, storytellers more and more make use of a pattern she defines as the 'self-realisation narrative' in shaping their biographies. This narrative pattern has mainly developed through the influence of psychological and psychotherapeutic theories on the cultural mainstream.

For the present investigation, we intend to adopt the method of narrative and biography analysis (Riessmann, 1993; Josselson and Lieblich, 1995; Lieblich et al., 1998) in order to look for those patterns in autobiographical stories of athletes that inspire their identities and influence their sports performance.

\section{Methodology: phrasal storytelling through manual content analysis}

The exploratory study was conducted by adopting a qualitative methodology and using the manual content analysis technique of interviews by sports athletes performed with the help of Microsoft Excel. Content analysis is one of the techniques used for the investigation of narratives, especially narrative identity constructs through storytelling (Smith, 2000; McLamore and Uluğ, 2020). This technique allows researchers and practitioners to obtain valuable, reliable and valid information from narratives that provide interesting inputs. Indeed, it represents a data analysis technique that can overcome the limits regarding the mere counting of words in the interpretation of the underlying context and meanings of the content with the aim of classifying large amounts of text into efficient categories able to group similar meanings.

In the present study, by using the method of narrative and biography analysis, the autobiographical stories of athletes will be explored, focusing on those elements that affect and define their identities and sports performance, thus counting and categorising through a manual content analysis their words and sentences linking them to the significant features taken into account. The manual content analysis has considered all the primary and secondary data sources. In particular, the 'portrait' of the narratives by sports athletes is built by collecting and elaborating information and data through specialised and general websites, 
press and magazines, and blogs. The websites and all the other sources have been analysed so as to identify the most representative and significant narratives detected in the statements made by athletes.

\section{What athletes declare about their life: results and discussion}

This section is devoted to a brief analysis of some sentences and expressions used by sports athletes worldwide, which can be read through a narrative identity construct using the content analysis previously described. More specifically, Table 5.1 shows ten sentences extracted from athletes' interviews available and collected through websites, blogs, press and magazines. Different nationalities were chosen, with a prevalence of Italian athletes and no particular sports discipline preference. Furthermore, ransom cases have been included through sports for athletes who have been attacked and lived shock events, and as in the case of Manuel Bortuzzo, this has changed his life forever.

The athletes' sentences are almost always used as aphorisms or examples for everyone. They are often sign of personal and social redemption. Almost always, they have an example value while representing a personal experience. They are often linked to an athletic moment but also a career. They are a reference point for the community.

Table 5.1 shows examples of athletes aware of being part of history, such as Ayrton Senna or Diego Armando Maradona, who were aware of the epic that approached their exploits and, therefore, pose the problem of the example, to semi-unknown and now emerging athletes who, for this reason, in their statements are more focused on the personal importance of the occasion that presents itself to them.

An interesting feature can be underlined in how individual sports athletes are more strongly identified than those who are part of a team and, for this reason, refer to greater collegiality. Another interesting aspect is represented by those who have gone from the role of players to that of coaches who perhaps play a more stimulating role.

\begin{tabular}{|c|c|c|c|c|}
\hline Athlete & Nation & Sport & Special condition & Quote \\
\hline $\begin{array}{l}\text { Federica } \\
\text { Pellegrini }\end{array}$ & Italy & Swimming & $\begin{array}{l}\text { Extremely long } \\
\text { career }\end{array}$ & $\begin{array}{l}\text { [after Korea World } \\
\text { Championship] "The reasons } \\
\text { for staying up high can be } \\
\text { found within you by setting } \\
\text { yourself goals that will surely } \\
\text { change over the years". }\end{array}$ \\
\hline $\begin{array}{l}\text { Roberta } \\
\text { Bruni }\end{array}$ & Italy & Athletics & & $\begin{array}{l}\text { [after winning Universiadi] "I } \\
\text { came out of all the tunnels, } \\
\text { even from the depression". }\end{array}$ \\
\hline $\begin{array}{l}\text { Manuel } \\
\text { Bortuzzo }\end{array}$ & Italy & Swimming & $\begin{array}{l}\text { This athlete was } \\
\text { seriously injured } \\
\text { by mistake in an } \\
\text { ambush and went } \\
\text { from being a } \\
\text { swimming promise } \\
\text { to fighting to }\end{array}$ & $\begin{array}{l}\text { [after the aggression] "How do } \\
\text { I see myself in } 10 \text { years? I hope } \\
\text { to stand up. To look forward, } \\
\text { you don't have to look back. } \\
\text { My life is always the same. } \\
\text { There is a logistical problem, } \\
\text { but they are the same as } \\
\text { always. I could beat my head }\end{array}$ \\
\hline
\end{tabular}




\begin{tabular}{|c|c|c|c|c|}
\hline Athlete & Nation & Sport & Special condition & Quote \\
\hline & & & $\begin{array}{l}\text { regain an everyday } \\
\text { life. }\end{array}$ & $\begin{array}{l}\text { and not be myself anymore. } \\
\text { Meet who shot me? I wouldn't } \\
\text { change anything, and I think I } \\
\text { would laugh because it didn't } \\
\text { make sense what they did". }\end{array}$ \\
\hline $\begin{array}{l}\text { Daisy } \\
\text { Osakue }\end{array}$ & Italy & Athletics & $\begin{array}{l}\text { Victim of a racist } \\
\text { attack. Italian but } \\
\text { Nigerian born. }\end{array}$ & $\begin{array}{l}\text { [after the aggression] "The eye } \\
\text { hurts, and it hurts even more to } \\
\text { know that there are people } \\
\text { who go around having fun like } \\
\text { this, but I don't give up! I am } \\
\text { coloured, proud of my origins, } \\
\text { but I feel very Italian - he } \\
\text { underlines - to get to wear the } \\
\text { blue jersey must be a great } \\
\text { effort: those who don't like it } \\
\text { that black athletes do usually } \\
\text { speak from the sofa...". }\end{array}$ \\
\hline $\begin{array}{l}\text { Rafael } \\
\text { Nadal }\end{array}$ & Spain & Tennis & $\begin{array}{l}\text { Extremely long } \\
\text { career }\end{array}$ & $\begin{array}{l}\text { [Wimbledon 2018] "Mental } \\
\text { strength distinguishes samples } \\
\text { from quasi-champions." }\end{array}$ \\
\hline $\begin{array}{l}\text { Ayrton } \\
\text { Senna }\end{array}$ & Brazil & Formula 1 & & $\begin{array}{l}\text { "In Formula 1, there is no curve } \\
\text { where it cannot be surpassed. } \\
\text { In life too". }\end{array}$ \\
\hline $\begin{array}{l}\text { Lance } \\
\text { Armstrong }\end{array}$ & USA & Cycling & $\begin{array}{l}\text { Important health } \\
\text { problems }\end{array}$ & $\begin{array}{l}\text { "I am convinced that every } \\
\text { human being has a finite } \\
\text { number of heartbeats. I do not } \\
\text { intend to waste my running } \\
\text { around doing exercises". }\end{array}$ \\
\hline $\begin{array}{l}\text { John James } \\
\text { Patrick }\end{array}$ & $\begin{array}{l}\text { New } \\
\text { Zealand }\end{array}$ & Rugby & Coach in Italy & $\begin{array}{l}\text { "I want the Italians to play } \\
\text { rugby as they drive: without } \\
\text { fear, aggressive and absolutely } \\
\text { unpredictable". }\end{array}$ \\
\hline Boris Becker & Germany & Tennis & & $\begin{array}{l}\text { "When you are young, you are } \\
\text { looking for your identity, and } \\
\text { winning is a way to express } \\
\text { yourself. When I lost, I wanted } \\
\text { to die; and since with the } \\
\text { victory I became someone, } \\
\text { consequently, in the defeat I } \\
\text { was nobody". }\end{array}$ \\
\hline $\begin{array}{l}\text { Diego } \\
\text { Armando } \\
\text { Maradona }\end{array}$ & Argentina & Football & & $\begin{array}{l}\text { [July } 5,1984 \text {, at the official } \\
\text { presentation at the San Paolo } \\
\text { stadium in front of } 70,000 \\
\text { spectators] "I want to become } \\
\text { the idol of the poor boys of } \\
\text { Naples because they are like } \\
\text { me in Buenos Aires". }\end{array}$ \\
\hline
\end{tabular}

Table 5.1. Summary of narrative identity examples in the sport setting. 
The narration of these ten statements highlights how these athletes have represented their identity, history and progress that has built and modified their life as athletes, on the one hand, and women and men, on the other hand. The first athlete analysed in Table 5.1 is Federica Pellegrini, one of the longest-lived swimmers in the history of this sport. She highlights the difficulty of being at extremely high-performance levels for such a long period. Her lexicon ties her goals to a long, incredibly long period, in which ups and downs are physiological but not for those who are always beyond the threshold of success. Thus, Roberta Bruni, winner of the Universiadi, underlines how sports are the solution for change, as she comes out of the tunnel of depression with athletic success. She states that the change towards victory has taken away the dark evil. Manuel Bortuzzo, a promising athlete who has risen to the headlines for a casual injury but who has changed his young life forever, reveals in the words that he uses irony, a bitter sarcasm that represents all the strength of an athlete who faces his most difficult challenge. That change, in this definitive case, which in the narration even more parallels sport and life. Daisy Osakue, on the other hand, is an athlete who highlights in her interviews how racist aggressions suffered based on the colour of her skin and which had a peak in real physical aggression, gave her an even clearer commitment in sport and in what for her it meant in affirming her identity as a person and not as a woman belonging to a race. Rafael Nadal is still a tennis player famous for his res palm but perhaps equally famous for his attitude to victory. His sentences are often ironic but, at the same time, epic; also in this case, they represent an exceptional career but full of accidents and difficulties to overcome. Ayrton Senna left posterity with an almost mythical statement, his life was a circuit, and his difficulties the curves to overcome, none is impossible, a phrase that then became an accurate aphorism where the word 'curve' evokes the need for 'overcoming'. Lance Armstrong, in his statement, underlines the passage from the temporal narrative (i.e., the heartbeat of the training) to the eternity of the athletic gesture: the daily duration of an exercise is projected into the durability of the sporting enterprise, from its affirmation this is out with clarity and emphasis. John James Patrick was first an athlete and then a coach. It was not easy for him to work in a country where rugby is loved but less than other sports, and his interviews have always aimed at improving not only his identity as a coach but also highlighting the construction of national identity in the sense of this sport. He compares automobile circuits and oval ball sport, and unsurprisingly, he tries to overcome cultural barriers. Boris Becker has instead distinguished himself for a career that started when he was particularly young, and that led him to develop resilience after the normal defeats that occurred; the strength was his resilience in a career that had two distinct phases, and his interviews have always highlighted these two different eras. Maradona closes the storytelling overview: when, as a young leading footballer in the world, he arrived in Naples from his very poor origins that he never forgot to mention in his outpourings, football was a way to socially emancipate himself, and this transpires from his famous sentences.

\section{Conclusions}

The debate on the issues in the sports setting investigated in the present paper is particularly heated and still open, although research is scant yet. This exploratory study has thus provided a short description of narrative identity constructs outlining their effects on athletes' performance in the sport setting. Therefore, the study aims to explore the existence and direction of the relationship between self-narrative modalities, the significant psychological 
states they feed and the performance components they impact, in light of the theories developed over the last two decades on the subject. In order to achieve this purpose, a descriptive table has been built on a specified panel of stories of successful athletes, chosen as focus groups, investigated using a manual content analysis technique for storytelling, in the preliminary phase with respect to subsequent qualitative analysis of the content that will be applied to a reasoned sample of athletes.

It would be interesting to analyse these issues, outlining if and how there are significant differences for athletes because of their social background, sports discipline and personality traits. In the future, after a clear systematic review on the topics, combining narrative identity constructs and performance in a sports setting and also using statistical programs, we can develop this first short research identifying interesting individual and organisational variables, such as personality traits, coaching style, workplace climate, stress, etc.) which can significantly impact on the phenomenon.

This study should give valuable suggestions for future research exploring the effect of rational interventions on athletes' storytelling and storytelling intervention on unsuccessful athletes' mental state and performance. Otherwise, it might be interesting to focus on digital storytelling intervention, taking into account the advent and spread of digital technologies also for narratives and storytelling issues.

Digital storytelling refers to a narrative form of video intervention in which an individual is able to record and share a significant life experience, ideas or feelings, through the creation of a brief story using digital means (Center for Digital Storytelling 2019). Thus, digital media have been used within digital storytelling interventions, such as sounds (audio narration, music), images, and texts in storytelling practice for promoting intrapersonal and interpersonal dialogues, and positive health behaviour and sport performance changes (Chan and Holosko, 2017; Chan, 2019).

\section{Keywords}

narrative identity; sport; performance; athletes; storytelling; self-awareness

\section{References}

Adisa, T.A., Gbadamosi, G., and Osabutey, E.L. (2017), “What Happened to the Border? The Role of Mobile Information Technology Devices on Employees' Work-Life Balance", Personnel Review, 46 (8): 1651-1671. DOI: 10.1108/PR-08-2016-0222.

Adler, J.M. (2012), "Living into the Story: Agency and Coherence in a Longitudinal Study of Narrative Identity Development and Mental Health over the Course of Psychotherapy", Journal of Personality and Social Psychology, 102: 367-389.

Baerger, D.R., and McAdams, D.P. (1999), "Life Story Coherence and Its Relation to Psychological Well-Being", Narrative Inquiry, 9 (1): 69-96.

Basu, R., and Kumar, S. (2020), "Awareness, Attitude and Social Identity in the Contemporary Globalized World: An Exploratory Study of Emerging Adults", International Journal of Recent Research in Social Sciences and Humanities (IJRRSSH), 7 (1): 1-9. 
Bauer, J.J., McAdams, D.P., and Sakaeda, A. (2005), "Interpreting the Good Life: Growth Memories in the Lives of Mature, Happy People", Journal of Personality and Social Psychology, 88: 203-217.

Bruner, J. (1995), “The Narrative Construction of Reality”, Critical Inquiry, 18: 1-21.

Centre for Substance Abuse Treatment (2008), Managing Depressive Symptoms in Substance Abuse Clients during Early Recovery, Rockville, MD: Substance Abuse and Mental Health Services Administration (US). Available online at https://www.ncbi.nlm.nih.gov/books/NBK64057/ (last accessed: November 21, 2020).

Chamberlayne, P. (ed.) (2000), The Turn to Biographical Methods in Social Science: Comparative Issues and Examples, London: SAGE.

Chan, C. (2019), “Using Digital Storytelling to Facilitate Critical Thinking Disposition in Youth Civic Engagement: A Randomized Control Trial", Children and Youth Services Review, 107: 1-10. DOI: 10.1016/j.childyouth.2019.104522.

Chan, C., and Holosko, M.J. (2017), "The Utilization of Social Media for Youth Outreach Engagement: A Case Study", Qualitative Social Work, 16 (5): 680-697.

Covington, C. (1995), “No Story, No Analysis? The Role of Narrative in Interpretation”, Journal of Analytical Psychology, 40: 405-417.

Cunningham, R., Bunde-Birouste, A., Rawstorne, P., and Nathan, S. (2020), “Young People's Perceptions of the Influence of a Sport-for-Social-Change Program on Their Life Trajectories", Social Inclusion, 8 (3): 162-176.

Davis, A., and Weinshenker, D. (2012), "Digital Storytelling and Authoring Identity", in C. Ching and B. Foley (eds), Constructing the Self in a Digital World, pp. 47-74, Cambridge: Cambridge University Press. DOI: 10.1017/CBO9781139027656.005.

Den Hartigh, R.J., Niessen, A.S.M., Frencken, W.G., and Meijer, R.R. (2018), “Selection Procedures in Sports: Improving Predictions of Athletes' Future Performance", European Journal of Sport Science, 18 (9): 1191-1198.

Ellis, C. (2007), “Telling Secrets, Revealing Lives: Relational Ethics in Research with Intimate Others", Qualitative Inquiry, 13 (1): 3-29.

Erikson, E.H. (1950), Childhood and Society, New York, NY: Norton.

Erikson, E.H. (1963), Childhood and Society (2nd edn.), New York, NY: Norton.

Erikson, E.H. (1968), Identity: Youth and Crisis, New York, NY: Norton.

Etzel, E.F. (2006), “Understanding and Promoting College Student-Athlete Health: Essential Issues for Student Affairs Professionals", Journal of Student Affairs Research and Practice, 43 (3): 894-922.

Ferreri, E. (2020), "Violence, Identity and Culture: Perspectives and Topics in the Global Scenarios", International Review of Sociology, 30 (2): 1-19. DOI: 10.1080/03906701.2020.1807863.

Fivush, R., Haden, C.A., and Reese, E. (2006), “Elaborating on Elaborations: Role of Maternal Reminiscing Style in Cognitive and Socioemotional Development", Child Development, 77: 1568-1588.

Gallie, D. (2019), "Research on Work Values in a Changing Economic and Social Context", The Annals of the American Academy of Political and Social Science, 682 (1): 26-42. 
Gergen, K.J., and Gergen, M.M. (1987), “The Self in Temporal Perspective”, in R.P. Abeles (ed.), Life-Span Perspectives and Social Psychology, pp. 121-137, Hillsdale, NJ: Lawrence Erlbaum Associates, Inc.

Gergen, M.M. (1996), “The Social Construction of Personal Histories: Gendered Lives in Popular Autobiographies", in T.R. Sarbin and J.I. Kitsuse (eds), Constructing the Social, 19-44, London: SAGE.

Granter, E., McCann, L., and Boyle, M. (2015), “Extreme Work/Normal Work: Intensification, Storytelling and Hypermediation in the (Re)Construction of 'the New Normal'", Organization, 22 (4): 443-456. DOI: 10.1177/1350508415573881.

Guzman, A.L., and Lewis, S.C. (2020), “Artificial Intelligence and Communication: A HumanMachine Communication Research Agenda", New Media \& Society, 22 (1): 70-86.

Habermas, T., and Bluck, S. (2000), "Getting a Life: The Emergence of the Life Story in Adolescence", Psychological Bulletin, 126: 748-769.

Habermas, T., and de Silveira, C. (2008), "The Development of Global Coherence in Life Narratives across Adolescence: Temporal, Causal, and Thematic Aspects", Developmental Psychology, 44: 707-721.

Haudenhuyse, R. (2017), "Introduction to the Issue Sport for Social Inclusion: Questioning Policy, Practice and Research", Social Inclusion, 5 (2): 85-90.

Hughes, B., and Paterson, K. (1997), "The Social Model of Disability and the Disappearing Body: Toward a Sociology of Impairment", Disability and Society, 12 (3): 325-340.

Hydén, L.C. (2010), “Identity, Self, Narrative”, Beyond Narrative Coherence, 11: 33-47.

Jamissen, G., and Skou, G. (2010), "Poetic Reflection through Digital Storytelling: A Methodology to Foster Professional Health Worker Identity in Students", Seminar.net, 6 (2): 177-191.

Josselson, R., and Lieblich, A. (eds) (1995), Interpreting Experience. The Narrative Study of Lives, London: SAGE.

Jung, C.G. (1995 [1911-1912/1952]), Collected Works, Vol. 5: Symbols of Transformation (2nd edn.), London: Routledge and Kegan Paul.

Kerby, A.P. (1991), Narrative and the Self, Bloomington, IN: Indiana University Press.

King, L.A., and Hicks, J.A. (2007), “Whatever Happened to 'What Might Have Been'”, American Psychologist, 62: 625-636.

Leiser, D., Benita, R., and Bourgeois-Gironde, S. (2016), “Differing Conceptions of the Causes of the Economic Crisis: Effects of Culture, Economic Training, and Personal Impact", Journal of Economic Psychology, 53: 154-163.

Lieblich, A., Tuval-Mashiach, R., and Zilber, T. (1998), Narrative Research: Reading, Analysis and Interpretation, London: SAGE.

Linde, C. (1993), Life Stories: The Creation of Coherence, Oxford: Oxford University Press.

Marks, D. (1999), “Dimensions of Oppression: Theorising the Embodied Subject”, Disability $\mathcal{E}$ Society, 14 (5): 611-626.

McAdams, D.P. (1985), Power, Intimacy, and the Life Story: Personological Inquiries into Identity, Homewood, IL: Dorsey Press.

McAdams, D.P. (1993), Personal Myths and the Making of the Self, New York, NY: Morrow. 
McAdams, D.P. (1993), The Stories We Live By, New York, NY: HarperCollins.

McAdams, D.P. (1995), "What Do We Know When We Know a Person?", Journal of Personality, 63, 365-396.

McAdams, D.P. (1996), "Personality, Modernity, and the Storied Self: A Contemporary Framework for Studying Persons", Psychological Inquiry, 7: 295-321.

McAdams, D.P., and McLean, K.C. (2013), "Narrative Identity", Current Directions in Psychological Science, 22 (3): 233-238.

McLamore, Q., and Uluğ, Ö.M. (2020), "Social Representations of Sociopolitical Groups on r/The_Donald and Emergent Conflict Narratives: A Qualitative Content Analysis", Analyses of Social Issues and Public Policy, 20 (1): 508-535. DOI: 10.1111/asap.12212.

McLean, K.C., and Pratt, M.W. (2006), “Life's Little (and Big) Lessons: Identity Status and Meaning-Making in the Turning Point Narratives of Emerging Adults", Developmental Psychology, 42: 714-722.

McLean, K.C., and Pasupathi, M. (2011), “Old, New, Borrowed, Blue? The Emergence and Retention of Personal Meaning in Autobiographical Storytelling", Journal of Personality, 79: 135-163.

McLean, K.C., Pasupathi, M., and Pals, J.L. (2007), “Selves Creating Stories Creating Selves: A Process Model of Self-Development", Personality and Social Psychology Review, 11: 262278.

Mishler, E.G. (1986), Research Interviewing: Context and Narrative, Cambridge, MA: Harvard University Press.

Pals, J.L. (2006), “Constructing the 'Springboard Effect': Causal Connections, Self-Making, and Growth within the Life Story", in D.P. McAdams, R. Josselson and A. Lieblich (eds), Identity and Story: Creating Self in Narrative, pp. 175-199, Washington, DC: APA Books.

Pappous, A., Marcellini, A., and de Leseleuc, E. (2011), “From Sydney to Beijing: The Evolution of the Photographic Coverage of Paralympic Games in Five European Countries", Sport in Society, 14 (3): 345-354.

Pasupathi, M., and Hoyt, T. (2010), "Silence and the Shaping of Memory: How Distracted Listeners Affect Speakers' Recall of a Computer Game Experience", Memory, 18: 159-169.

Paterson, K., and Hughes, B. (1999), “Disability Studies and Phenomenology: The Carnal Politics of Everyday Life", Disability \& Society, 14 (5): 597-610.

Peachey, J.W., Schulenkorf, N., and Spaaij, R. (2019), “Sport for Social Change: Bridging the Theory-Practice Divide", Journal of Sport Management, 33 (5): 361-365.

Perrier, M.J., Smith, B., and Latimer-Cheung, A.E. (2013), "Narrative Environments and the Capacity of Disability Narratives to Motivate Leisure-Time Physical Activity among Individuals with Spinal Cord Injury", Disability and Rehabilitation, 35 (24): 2089-2096.

Perrier, M.J., Strachan, S.M., Smith, B., and Latimer-Cheung, A.E. (2014), "Narratives of Athletic Identity after Acquiring a Permanent Physical Disability", Adapted Physical Activity Quarterly, 31 (2): 106-124.

Pitts, B.G., and Zhang, J.J. (eds) (2020), Sport Business in the United States: Contemporary Perspectives, London/New York: Routledge. 
Polkinghorne, D.E. (1996), "Explorations of Narrative Identity", Psychological Inquiry, 7: 363367.

Rao, A.L., and Hong, E.S. (2016), “Understanding Depression and Suicide in College Athletes: Emerging Concepts and Future Directions", British Journal of Sports Medicine, 50 (3): 136137. DOI: 10.1136/bjsports-2015-095658.

Riessman, C.K. (1993), Narrative Analysis, Newbury Park, CA: SAGE.

Rizvandi, A., Taghipour Gharbi, M., Esmaeili, M., and Ashraf Ganjoee, F. (2019), "The Evaluation of Performance Indicators of Coaches in Football Development", Journal of Humanities Insights, 3 (4): 248-254.

Roesler, C. (2006), “A Narratological Methodology for Identifying Archetypal Story Patterns in Autobiographical Narratives", Journal of Analytical Psychology, 51 (4): 574-586.

Sarokhani, D., Delpisheh, A., Veisani, Y., Sarokhani, M.T., Manesh, R.E., and Sayehmiri, K. (2013), "Prevalence of Depression among University Students: A Systematic Review and Meta-Analysis Study", Depression Research and Treatment, 1: 1-7. DOI: $10.1155 / 2013 / 373857$.

Smith, B., and Sparkes, A.C. (2012), “Disability, Sport and Physical Activity: A Critical Review", in N. Watson, A. Roulstone and C. Thomas (eds), Routledge Handbook of Disability Studies, pp. 336-347, London: Routledge.

Smith, C.P. (2000), "Content Analysis and Narrative Analysis", in H.T. Reis and C.M. Judd (eds), Handbook of Research Methods in Social and Personality Psychology, pp. 313-335, New York, NY: Cambridge University Press.

Storch, E.A., Storch, J.B., Welsh, E., and Okun, A. (2002), "Religiosity and Depression in Intercollegiate Athletes", College Student Journal, 36 (4): 526-532.

Syed, M., and Azmitia, M. (2010), “Narrative and Ethnic Identity Exploration: A Longitudinal Account of Emerging Adults' Ethnically-Related Experiences", Developmental Psychology, 46: 208-219.

Trinh, C.T., Nguyen, X., Sgro, P., and Pham, C.S. (2020), “Culture, Financial Crisis and the Demand for Property, Accident and Health Insurance in the OECD Countries", Economic Modelling, 93: 480-498.

Wake, D.G. (2012), "Exploring Rural Contexts with Digital Storytelling”, The Rural Educator, 33 (3): 23-36. DOI: 10.35608/ruraled.v33i3.409.

Wang, B., Liu, Y., and Parker, S.K. (2020), “How Does the Use of Information Communication Technology Affect Individuals? A Work Design Perspective", Academy of Management Annals, 14 (2): 695-725. DOI: 10.5465/annals.2018.0127.

Waters, T.E., and Fivush, R. (2015), "Relations between Narrative Coherence, Identity, and Psychological Well-Being in Emerging Adulthood", Journal of Personality, 83 (4): 441-451.

Yang, J., Peek-Asa, C., Corlette, J.D., Cheng, G., Foster, D.T., and Albright, J. (2007), "Prevalence of and Risk Factors Associated with Symptoms of Depression in Competitive Collegiate Student Athletes", Clinical Journal of Sport Medicine, 17 (6): 481487. 